\title{
Parathyroid Hormone Response to Vitamin D Insufficiency in Elderly Males With Chronic Heart Failure
}

\author{
B. BOZIC ${ }^{1,2}$, G. LONCAR ${ }^{3}$, N. PRODANOVIC ${ }^{4}$, T. LEPIC ${ }^{5}$, Z. RADOJICIC ${ }^{6}$, \\ V. CVOROVIC ${ }^{7}$, S. DIMKOVIC ${ }^{3}$, V. POPOVIC ${ }^{8}$
}

${ }^{1}$ Institute for Medical Research, Military Medical Academy, Belgrade, Serbia, ${ }^{2}$ Institute for Physiology and Biochemistry, University of Belgrade, Serbia, ${ }^{3}$ Cardiology Department, Clinical Medical Center Zvezdara, Belgrade, Serbia, ${ }^{4}$ Clinic for Rheumatology and Clinical Immunology, Military Medical Academy, Belgrade, Serbia, ${ }^{5}$ Clinic for Neurology, Military Medical Academy, Belgrade, Serbia, ${ }^{6}$ Institute for Statistics, Faculty of Organizational Sciences, University of Belgrade, Serbia, ${ }^{7}$ Clinical Hospital Center Zemun, Belgrade, Serbia, ${ }^{8}$ Institute of Endocrinology, University Clinical Center of Serbia, Belgrade, Serbia

Received January 4, 2011

Accepted March 30, 2011

On-line July 19, 2011

\section{Summary}

Secondary hyperparathyroidism (SHPT) may contribute to the systemic illness that accompanies chronic heart failure (CHF). Healthy elderly with vitamin $D$ deficiency who did not develop hyperparathyroidism (functional hypoparathyroidism, FHPT) had lower mortality than those who did. This study was designed to examine determinants of the PTH response in the vitamin D insufficient CHF patients. Sixty five vitamin D insufficient males with NYHA class II and III and 20 control subjects age $\geq 55$ years were recruited. Echocardiography, physical performance, NT-pro-BNP, PTH, 25-hydroxyvitamin D (25(OH)D), adiponectin and bone activity surrogate markers (OPG, RANKL, OC, $\beta-C T x$ ) were assessed. Increased NYHA class was associated with SHPT, while physical performance was inferior compared to FHPT. SHPT was associated with lower left ventricular ejection fraction (LVEF) and flow mediated dilatation, but with higher left heart dimensions, left ventricular mass index and right ventricular systolic pressure. CHF patients with SHPT had increased NT-proBNP, adiponectin and bone markers, but decreased 25(OH)D compared to those with FHPT. Independent determinants for SHPT in CHF patients with vitamin D insufficiency were LVEF, adiponectin and $\beta-C T x$, irrespective of renal function and serum vitamin D levels. In conclusion, increased PTH levels, but not low vitamin $D$, demonstrated close relation to CHF severity.

\section{Key words}

Heart failure - PTH • Response - Vitamin D insufficiency • Adiponectin • Bone markers

\section{Corresponding author}

V. Popovic, Neuroendocrine Unit, Institute of Endocrinology, University Clinical Center of Serbia, Dr Subotic 13, 11000 Belgrade, Serbia. Fax: +381 112685 357. E-mail: popver@eunet.rs

\section{Introduction}

Chronic heart failure (CHF) and osteoporosis are two common chronic conditions in elderly people that are gaining importance for healthcare. These conditions associated with poor quality of life and increased morbidity/ mortality (Levy et al. 2002, Bleumink et al. 2004). Worldwide, the prevalence of vitamin D deficiency is a high as almost $50 \%$ among the elderly, as well (Mosekilde 2005). Traditionally, vitamin D has been associated primarily with bone health. However, recently extended by reports with evidences that adequate vitamin D status is important for optimal function of many organs and tissues throughout the body, including the cardiovascular system. Vitamin D inadequate status linking with various disease including arterial hypertension and diabetes mellitus, as well (Forman et al. 2007, Pittas et al. 2007).

CHF results not only from cardiac overload or injury but also from a complex interplay among genetic, neurohormonal, inflammatory and biochemical changes 
(Braunwald 2008). Patients with CHF have been reported to have lower bone mineral density (BMD), in part related to lower vitamin D status and higher frailty rates (Kenny et al. 2006). High levels of serum parathyroid hormone (PTH) have been previously reported in CHF patients (Shane et al. 1997). It has also been reported that secondary hyperparathyroidism (SHPT) may contribute to the systemic illness that accompanies heart failure (Alsafwah et al. 2007). The age related rise in serum PTH can be accounted for by the age-related fall in serum 25-hydroxyvitamin D (25(OH)D) and/or decline in renal function with consequent loss of the calcemic action of vitamin D on bone (Lips 2001, Mosekilde 2005). The relation between PTH levels with different parameters of heart failure is modestly presented in the literature (Garakyaraghi et al. 2009). Recent study in healthy elderly demonstrated that in the presence of vitamin D deficiency, those who did not develop hyperparathyroidism had lower mortality than those who did (Chen et al. 2008). This blunted PTH response has been termed as functional hypoparathyroidism (FHPT) (Sahota et al. 2001, 2006). Previous studies also in healthy subjects indicate functional hypoparathyroidism in vitamin D deficiency is not so uncommon (Souberbielle et al. 2001, Isaia et al. 2003, Vieth et al. 2003). In this study we aimed to examine determinants of the PTH response (SHPT vs FHPT) in the vitamin D insufficient group of CHF patients.

\section{Methods}

\section{Study design}

Having medical history archives of the Cardiology Department, Clinical Medical Center Zvezdara Belgrade reviewed, first contacts with eligible patients were made on the phone. For the baseline visit we screened 152 males aged 55 years and above with chronic heart failure (CHF) due to ischemic or idiopathic dilated cardiomyopathy. Following the baseline visit 73 patients were included all of whom met the study inclusion and exclusion criteria. Inclusion criteria were: 1. duration of CHF for longer than one year; 2. echocardiographically assessed left ventricular ejection fraction $<40 \%$; 3. etiology of CHF: ischemic or idiopathic dilated cardiomyopathy; 4. NYHA functional class II and III; 5 . unchanged medication regimen within the previous 6 weeks; 6. clinically stable condition with no clinical evidence of decompensate heart failure, such as raised jugular venous pressure, ascites, hepatomegaly. Exclusion criteria were: 1 . diabetes mellitus determined by either self- reported histories or evidence within the hospital case notes; 2. primary lung disease including chronic obstructive pulmonary disease; 3. musculoskeletal diseases; 4. uncontrolled hypertension of more than $170 / 110 \mathrm{~mm} \mathrm{Hg}$; 5. myocardial infarction or unstable angina within previous 3 months; 6 . acute or chronic infection, inflammatory diseases such as sepsis, arthritis or systemic connective tissue disease; 7. symptomatic peripheral vascular disease; 8. alcohol abuse; 9. serum creatinine $\geq 200 \mu \mathrm{mol} / \mathrm{l} ; 10$. valvular cardiomyopathy or artificial heart valve; 11. malignant disease, significant liver, thyroid, suprarenal gland or pituitary disease; 12. cardiac cachexia defined as unintentional weight loss of $\geq 7.5 \%$ body weight over 6 months (Anker et al. 1997). Sixty five patients of included 73 patients had vitamin D insufficiency $(<50 \mathrm{nmol} / \mathrm{l})$ were studied. Twenty healthy male volunteers aged 55 years and above, who did not take medications, formed the control group. No previous medical illness was reported (including diabetes or any other cardiovascular disease). Written informed consent was obtained from all patients with CHF and healthy subjects prior to inclusion into the study. The study was conducted according to the principles outlined in the Declaration of Helsinki and was approved by Ethical Committee of Clinical Medical Center Zvezdara.

\section{Clinical and cardiovascular assessment}

After the patient gave his written consent, the medical history was reviewed, including the cause of heart failure, comorbidities and medical history. Each CHF patient was categorized according to the New York Heart Association (NYHA) criteria (The Criteria Committee of the New York Heart Association Criteria for diagnosis and treatment of heart failure 1994). A physical exam was performed to assess CHF stability. The six-minute walk test was performed according to the standard protocol (ATS statement: guidelines for the sixminute walk test 2002). All patients underwent a twodimensional Doppler echocardiography examination (GE Vivid 7) which was performed in the left lateral position. Systolic function was quantified by measurement of left ventricular ejection fraction (LVEF) using the Simpson method. We also measured left ventricular end-diastolic diameter (LVEDD), right ventricular systolic pressure (RVSP) and left atrial volume (LAV) according to the ASE recommendation (Silvestry et al. 2009). LVMi was calculated by dividing the value of LVM by body surface area. Grip strength was determined by Jamar dynamometer using standard protocol. Quality of life 
(QoL) was estimated from The "Minnesota-Living with Heart Failure Questionnaire" (MLHFQ) (Rector and Cohn 1992). Endothelium-dependent, flow mediated dilation (FMD) as a measure of endothelial function of the brachial artery was determined as previously described in details (Corretti et al. 2002).

\section{DEXA measurements}

A dual energy x-ray absorptiometry machine (Lunar prodigy advance, USA) was used, according to standard protocol, to measure BMD $\left(\mathrm{g} / \mathrm{cm}^{2}\right)$, total bone mineral content and body composition (lean and fat mass). BMD was measured at the lumbar spine, hip and hip total. The coefficient of variation of BMD measurement at the hip and lumbar spine was $<1 \%$. The difference between an individual's BMD and the mean BMD for a reference population was expressed in standard deviation term.

\section{Laboratory analysis}

Basal blood samples were taken at 8 am from an antecubital vein. Participants were asked to refrain from smoking more than $8 \mathrm{~h}$ before blood sampling, to be fasted from $9 \mathrm{pm}$ the previous evening as well as to withhold vasoactive medication for $12 \mathrm{~h}$ prior to appointment. Serum samples were immediately deep frozen and kept at $-70{ }^{\circ} \mathrm{C}$ until assay. Serum levels of parathyroid hormone (PTH), N-terminal-pro-B-type natriuretic peptide (NT-pro-BNP), osteocalcin (OC) and $\beta$-CrossLaps ( $\beta$-CTx) were measured with a fully automated "sandwich" electrochemiluminescence method using Elecsys analyzer (Roche Diagnostics, $\mathrm{GmbH}$, Mannheim; measuring range from $1.2-5000 \mathrm{pg} / \mathrm{ml}$, $5-35000 \mathrm{pg} / \mathrm{ml}, \quad 0.5-300 \mathrm{ng} / \mathrm{ml}$ and $10-6000 \mathrm{pg} / \mathrm{ml}$, respectively). Total adiponectin and leptin levels in serum were measured by RIA (Linco Diagnostics, Inc., St/ Charles, MO; lowest detectable concentration, $1 \mu \mathrm{g} / \mathrm{ml}$ and $0.5 \mathrm{ng} / \mathrm{ml}$, respectively). Commercial ELISA kits (Bender MedSystems GmbH, Austria) were used to measure serum levels of RANKL and OPG. The lower limits of detection were $2.2 \mathrm{pg} / \mathrm{ml}$ for RANKL and $2.5 \mathrm{pg} / \mathrm{ml}$ for OPG. Intra- and interassay coefficients of variation were $<7.8$ and $<7.2 \%$ for RANKL and $<7.0$ and $<8.0 \%$ for OPG, respectively. 25(OH)D was measured by chemiluminiscent immuno (CLIA) technology (DiaSorin Inc., USA; measuring range from 4-150 ng/ml). To convert results to $\mathrm{SI} \mathrm{ng} / \mathrm{ml} \mathrm{x}$ $2.5=\mathrm{nmol} / \mathrm{l}$. Estimated creatinine clearance was calculated from serum creatinine values using the
Cockroft-Gault formula (Cockroft and Gault 1976).

\section{Definition of parathyroid status}

Within CHF patients we selected those with vitamin $\mathrm{D}$ insufficiency defined as a $25(\mathrm{OH}) \mathrm{D}$ level below $50 \mathrm{nmol} / 1$. Sixty-five patients with vitamin D insufficiency were divided into tertiles of PTH status. Group of patients who responded with PTH level in the highest tertile were defined as secondary hyperparathyroidism (SHPT). Functional hypoparathyroidism (FHPT) were defined as those patients with PTH level in the lowest tertile, whereas patients with PTH level in the mid-tertile were defined as having an intermediate parathyroid status.

\section{Statistical analysis}

Descriptive statistics were presented as mean values with standard deviation or median with interquartile range for numeric variables, or as absolute numbers with percentages for categorical variables. Evaluation of normality was performed with Kolmogorov-Smirnov test. The $\log 10$-transformations were performed for OPG, RANKL and NT-pro-BNP, which follow exponential distribution. Student t-test was used to calculate differences between mean values. Mann-Whitney U-test was used to determine differences between median values. $\chi^{2}$-test was used to test cross tabulation for categorical variables between studied groups. Comparisons across three groups were done with ANOVA (group means). The Pearson coefficient was used for linear correlation between variables. Partial correlation analysis was performed to adjust for creatinine clearance. We used multivariable logistic regession to further examine the independent association between PTH status and variables that were significantly different between the high and low PTH groups. This was done by forward stepwise model with Nagelkerke's $R^{2}$ used to asses its explanatory ability. A $p$ value $\leq 0.05$ was considered to indicate statistical significance. Statistical analysis was performed using the SPSS software for Windows, version 15 (SPSS, Inc., Chicago, IL).

\section{Results}

Demographic and clinical characteristics of elderly $\mathrm{CHF}$ patients with vitamin D insufficiency according to $P T H$ response

The general characteristics of elderly $\mathrm{CHF}$ patients with vitamin D insufficiency according to PTH 
Table 1. Demographic, clinical and echocardiography characteristics in groups with different PTH response in CHF patients with vitamin $D$ insufficiency.

\begin{tabular}{|c|c|c|c|c|c|}
\hline & $\begin{array}{c}\text { Functional } \\
\text { hypoparathyroidism } \\
\text { (FHPT) } \\
\text { PTH } \leq 57 \\
(\mathrm{n}=\mathbf{2 2})\end{array}$ & $\begin{array}{c}\text { Intermadiate } \\
\text { PTH status } \\
\\
\begin{array}{c}\mathbf{5 7}<\text { PTH }<88 \\
\quad(\mathrm{n}=\mathbf{2 2})\end{array}\end{array}$ & $\begin{array}{c}\text { Secondary } \\
\text { hyperparathyroidism } \\
\text { (SHPT) } \\
\text { PTH } \geq 88 \\
(\mathrm{n}=\mathbf{2 1})\end{array}$ & $P$-ANOVA & $\begin{array}{c}P \text {-value } \\
\text { (FHPT } \\
\text { vs } \\
\text { SHPT) }\end{array}$ \\
\hline Age (years) & $67 \pm 7$ & $69 \pm 8$ & $67 \pm 9$ & 0.845 & 0.991 \\
\hline Waist/hip ratio & $1.02 \pm 0.05$ & $1.02 \pm 0.04$ & $1.04 \pm 0.04$ & 0.427 & 0.291 \\
\hline$B M I\left(\mathrm{~kg} / \mathrm{m}^{2}\right)$ & $28 \pm 5$ & $27 \pm 4$ & $29 \pm 7$ & 0.475 & 0.564 \\
\hline Duration of disease (years) & $6 \pm 4$ & $4 \pm 3$ & $6 \pm 5$ & 0.148 & 0.634 \\
\hline $\begin{array}{l}\text { Ischemic / idiopathic dilated } \\
C M P, n(\%)\end{array}$ & $18(82) / 4(18)$ & $18(82) / 4(18)$ & $18(86) / 3(14)$ & 0.829 & 0.736 \\
\hline NYHA class II/III, $n(\%)$ & $20(91) / 2(9)$ & $17(77) / 5(23)$ & $11(52) / 10(48)$ & 0.015 & $0.005 * *$ \\
\hline$M L H F Q$ & $25 \pm 13$ & $27 \pm 12$ & $39 \pm 15$ & 0.003 & $0.003 * *$ \\
\hline Six-min walking distance & $438 \pm 80$ & $390 \pm 72$ & $370 \pm 87$ & 0.021 & $0.007 * *$ \\
\hline Grip strength (kg) & $98 \pm 21$ & $93 \pm 19$ & $92 \pm 20$ & 0.647 & 0.397 \\
\hline Mean blood pressure ( $\mathrm{mm} \mathrm{Hg}$ ) & $105 \pm 10$ & $101 \pm 11$ & $99 \pm 11$ & 0.188 & 0.081 \\
\hline$F M D$ & $0.47 \pm 0.19$ & $0.43 \pm 0.15$ & $0.36 \pm 0.15$ & 0.085 & $0.029^{*}$ \\
\hline$L V E F$ & $32 \pm 6$ & $27 \pm 9$ & $27 \pm 7$ & 0.066 & $0.036^{*}$ \\
\hline$L V M i$ & $147 \pm 41$ & $156 \pm 43$ & $177 \pm 41$ & 0.066 & $0.023^{*}$ \\
\hline LVEDD & $64 \pm 9$ & $67 \pm 9$ & $69 \pm 6$ & 0.141 & $0.050^{*}$ \\
\hline$L A V$ & $79 \pm 28$ & $94 \pm 32$ & $114 \pm 55$ & 0.023 & $0.006^{* *}$ \\
\hline$R V S P$ & $37 \pm 12$ & $53 \pm 17$ & $48 \pm 16$ & 0.006 & $0.029^{*}$ \\
\hline Creatinine clearance & $70 \pm 22$ & $59 \pm 17$ & $64 \pm 26$ & 0.277 & 0.362 \\
\hline Loop diretics, $n(\%)$ & $17(77)$ & $17(77)$ & $20(95)$ & 0.196 & 0.089 \\
\hline
\end{tabular}

Data are expressed as mean \pm S.D. or absolute number (percentage). BMI, body mass index; CMP, cardiomyopathy; FMD, flow mediated dilatation; LAV, left atrial volume; LVMi, left ventricular mass index; LVWT, left ventricular wall thickness; MLHFQ, Minesota Living with Heart Failure Questionnaire; NYHA, New York Heart Association; RVSP, right ventricular systolic pressure.

response are summarized in Table 1. Atrial fibrillation was noted in $28 \%$, while pacemaker was implanted in $9 \%$ of patients. History of myocardial infarction was presented in $63 \%$ of patients. Angiotensin-converting enzyme inhibitors were presented in $79 \%$ of patients, $75 \%$ were on beta-blockers, and $83 \%$ of patients were on loop diuretics, $54 \%$ were on spironolactone, $65 \%$ were on aspirin and $26 \%$ on statins. Age, waist/hip ratio and body mass index did not differ between groups. SHPT was associated with increased NYHA functional class, while quality of life and physical performance was inferior compared to FHPT. In addition, SHPT was associated with lower LVEF and flow mediated dilatation, but with higher left heart dimensions, left ventricular mass index and right ventricular systolic pressure. In addition, FMD was decreased in SHPT patients compared to FHPT.
Bone mineral density and body composition of elderly CHF patients with vitamin D insufficiency according to PTH response

Total hip BMD was significantly lower in SHPT group of CHF patients compared to FHPT group (Table 2). On the other hand, hip and lumbar spine BMD, total bone mineral content, fat and lean mass were similar between studied groups.

Biohumoral parameters in groups of vitamin D insufficient $C H F$ patients with different PTH response

The biohumoral variables are shown in Table 3. CHF patients in SHPT group had significantly higher serum NT-pro-BNP and adiponectin, while serum 25-hydroxy vitamin D levels were lower compared to those with FHPT. In addition, uric acid, serum alkaline phosphatase, osteocalcin and $\beta$-CrossLaps levels were increased in SHPT group of CHF patients. There was no 
Table 2. Bone mineral density and body composition in groups with different PTH response in CHF patients with vitamin D insufficiency.

\begin{tabular}{|c|c|c|c|c|c|}
\hline & $\begin{array}{c}\text { Functional } \\
\text { hypoparathyroidism } \\
\text { (FHPT) } \\
\text { PTH } \leq \mathbf{5 7} \\
(\mathbf{n}=\mathbf{2 2})\end{array}$ & $\begin{array}{c}\text { Intermadiate } \\
\text { PTH status } \\
\text { 57 }<\text { PTH }<88 \\
\quad(n=22)\end{array}$ & $\begin{array}{c}\text { Secondary } \\
\text { hyperparathyroidis } \\
\text { m } \\
\text { (SHPT) } \\
\text { PTH } \geq \mathbf{8 8} \\
(\mathbf{n}=\mathbf{2 1})\end{array}$ & $\begin{array}{c}P- \\
\text { ANOVA }\end{array}$ & $\begin{array}{c}P \text {-value } \\
\text { (FHPT } \\
\text { vs } \\
\text { SHPT) }\end{array}$ \\
\hline BMD hip $\left(\mathrm{g} / \mathrm{cm}^{2}\right)$ & $0.935 \pm 0.152$ & $0.819 \pm 0.151$ & $0.905 \pm 0.164$ & 0.043 & 0.535 \\
\hline BMD hip (T score) & $-0.9 \pm 1.3$ & $-1.9 \pm 1.2$ & $-1.2 \pm 1.2$ & 0.021 & 0.502 \\
\hline BMD hip total $\left(\mathrm{g} / \mathrm{cm}^{2}\right)$ & $1.031 \pm 0.145$ & $0.892 \pm 0.160$ & $0.937 \pm 0.154$ & 0.013 & $0.047 *$ \\
\hline BMD hip total (T score) & $-0.4 \pm 1.1$ & $-1.5 \pm 1.2$ & $-1.1 \pm 1.1$ & 0.007 & $0.045^{*}$ \\
\hline$B M D L 1-4\left(\mathrm{~g} / \mathrm{cm}^{2}\right)$ & $1.167 \pm 0.196$ & $1.055 \pm 0.163$ & $1.092 \pm 0.187$ & 0.124 & 0.203 \\
\hline BMD L1-4 (T score) & $-0.4 \pm 1.6$ & $-1.4 \pm 1.4$ & $-1.0 \pm 1.6$ & 0.116 & 0.204 \\
\hline BMC total ( $\mathrm{kg})$ & $2.9 \pm 0.6$ & $2.8 \pm 0.5$ & $2.9 \pm 0.4$ & 0.831 & 0.684 \\
\hline Fat mass (kg) & $20.7 \pm 9.2$ & $21.5 \pm 9.3$ & $25.9 \pm 13.1$ & 0.244 & 0.143 \\
\hline Lean mass $(\mathrm{kg})$ & $54.1 \pm 8.0$ & $51.9 \pm 7.5$ & $58.6 \pm 11.5$ & 0.244 & 0.145 \\
\hline
\end{tabular}

Data are expressed as mean \pm standard deviation (mean \pm S.D.). $B M D$ - bone mineral density, $B M C$ - bone mineral content.

significant difference in micronutrients, leptin levels and creatinin clearance between studied groups.

\section{Multivariate logistic regression analysis}

A stepwise forward logistic regression was performed. Odds ratio (OR), $95 \%$ confidence intervals (95\% CI) and Nagelkerke's R squared $\left(\mathrm{R}^{2}\right)$ are presented for the last step (step 3) (Table 4). Independent association with PTH status, in CHF patients with vitamin $\mathrm{D}$ insufficiency, were noted for $\operatorname{LVEF}(\mathrm{P}=0.030)$, adiponectin $(\mathrm{P}=0.051)$ and $\beta$-CTx $(\mathrm{P}=0.007)$ which together had an $\mathrm{R}^{2}$ of 0.729 . As the odds ratio indicates, higher LVEF was associated with lower odds of being in the high PTH tertile (SHPT), whereas the opposite was true for adiponectin and $\beta$-CTx. Other variables had statistically insignificant contribution to the model including creatinine clearance and serum vitamin D levels.

\section{Discussion}

As far as we know, this is the first report of independent predictor of secondary hyperparathyroidism in elderly vitamin $\mathrm{D}$ insufficiency men with mild to moderate CHF. Our main finding is that diminished LVEF, increased adiponectin and $\beta$-CTx are independent determinants of secondary hyperparathyroidism (SHPT) in elderly CHF patients with vitamin D insufficiency irrespective of renal function and serum vitamin D levels.

The well-known reasons for bone loss in CHF patients could be low vitamin D levels, high PTH, diminished physical performance and specific drugs (vitamin $\mathrm{K}$ antagonists and loop diuretics) (Anker et al. 1999). In this study SHPT patients had lower hip total BMD and decreased 6-minute walk compared to FHPT. Eighty-one percent of our CHF patients had loop diuretics in their treatment, while around half patients have taken vitamin $\mathrm{K}$ antagonists.

Serum PTH levels increased as a function of NYHA classification. Recently, a relationship between the deteriorating NYHA functional classes in CHF patients with hyperparathyroidism has been reported (Garakyaraghi et al. 2009). Similarly, we demonstrated that increased serum PTH was associated with elevated left ventricular mass index and left ventricular wall thickness (Loncar et al. 2010). High prevalence of left ventricular hypertrophy, measured by left ventricular mass index in primary hyperparathyroidism has been already reported (Piovesan et al. 1999). After surgical removal of parathyroid gland, left ventricular mass index decreased. Men with left ventricular hypertrophy have higher PTH levels than men without left ventricular hypertrophy do (Saleh et al. 2003). In previous study we have shown that the relative risk of systolic $\mathrm{CHF}$ in elderly males was associated with elevated serum PTH levels above the calculated cut-off of $48 \mathrm{pg} / \mathrm{ml}$ 
Table 3. Biohumoral parameters in groups with different PTH response in CHF patients with vitamin D insufficiency.

\begin{tabular}{|c|c|c|c|c|c|}
\hline & $\begin{array}{c}\text { Functional } \\
\text { hypoparathyroidism } \\
\text { (FHPT) } \\
\text { PTH } \leq 57 \\
(\mathrm{n}=\mathbf{2 2})\end{array}$ & $\begin{array}{c}\text { Intermadiate } \\
\text { PTH status } \\
\begin{array}{c}57<\text { PTH }<88 \\
(n=22)\end{array}\end{array}$ & $\begin{array}{c}\text { Secondary } \\
\text { hyperparathyroidis } \\
\text { m } \\
\text { (SHPT) } \\
\text { PTH } \geq \mathbf{8 8} \\
(\mathbf{n}=\mathbf{2 1})\end{array}$ & $\begin{array}{c}P \text { - } \\
\text { ANOVA }\end{array}$ & $\begin{array}{c}P \text {-value } \\
\text { (FHPT } \\
\text { vs } \\
\text { SHPT) }\end{array}$ \\
\hline$N T-$ pro-BNP & $768(1405)$ & $1759(2802)$ & $2890(3985)$ & 0.003 & $0.001 * *$ \\
\hline $25(\mathrm{OH}) \mathrm{D}$ & $31.1 \pm 12.1$ & $30.0 \pm 10.4$ & $23.8 \pm 10.9$ & 0.080 & $0.037 *$ \\
\hline $\begin{array}{l}\text { Serum calcium } \\
(\mathrm{mmol} / \mathrm{l})\end{array}$ & $2.47 \pm 0.10$ & $2.45 \pm 0.11$ & $2.44 \pm 0.11$ & 0.648 & 0.354 \\
\hline $\begin{array}{l}\text { Serum phosphorus } \\
(\mathrm{mmol} / \mathrm{l})\end{array}$ & $1.06 \pm 0.24$ & $1.05 \pm 0.15$ & $1.13 \pm 0.17$ & 0.282 & 0.253 \\
\hline $\begin{array}{l}\text { Serum magnesium } \\
(\mathrm{mmol} / \mathrm{l})\end{array}$ & $0.89 \pm 0.12$ & $0.89 \pm 0.08$ & $0.96 \pm 0.16$ & 0.138 & 0.143 \\
\hline $\begin{array}{l}\text { Serum potassium } \\
(\mathrm{mmol} / \mathrm{l})\end{array}$ & $4.75 \pm 0.37$ & $4.68 \pm 0.55$ & $4.98 \pm 0.42$ & 0.099 & 0.066 \\
\hline $\begin{array}{l}\text { Serum sodium } \\
(\mathrm{mmol} / \mathrm{l})\end{array}$ & $144.39 \pm 2.36$ & $143.22 \pm 3.67$ & $144.35 \pm 2.50$ & 0.328 & 0.959 \\
\hline Urine calcium & $2.66 \pm 1.84$ & $1.94 \pm 1.16$ & $2.15 \pm 1.64$ & 0.300 & 0.338 \\
\hline Uric acid & $352 \pm 69$ & $432 \pm 87$ & $468 \pm 118$ & $<0.0001$ & $<0.0001 * * *$ \\
\hline$A L P$ & $70.5 \pm 27.7$ & $82.0 \pm 25.2$ & $89.5 \pm 32.0$ & 0.097 & $0.033^{*}$ \\
\hline$O C$ & $30.0 \pm 14.5$ & $42.5 \pm 21.7$ & $46.4 \pm 21.4$ & 0.020 & $0.008 * *$ \\
\hline$\beta-C T x$ & $348 \pm 186$ & $513 \pm 279$ & $682 \pm 312$ & $<0.0001$ & $<0.0001 * * *$ \\
\hline$O P G(p g / m l)$ & $98.1(839.9)$ & $62.6(266.4)$ & $97.2(497.2)$ & 0.681 & 0.936 \\
\hline RANKL $(\mathrm{pg} / \mathrm{ml})$ & $114.7(1308.8)$ & $126.0(1013.9)$ & $143.0(442.8)$ & 0.489 & 0.341 \\
\hline Adiponectin & $12.4 \pm 5.4$ & $17.5 \pm 9.2$ & $20.5 \pm 7.6$ & 0.003 & $0.001 * *$ \\
\hline Leptin $(n g / m l)$ & $6.8 \pm 3.9$ & $6.7 \pm 5.7$ & $9.1 \pm 9.7$ & 0.435 & 0.305 \\
\hline $\begin{array}{l}\text { Creatinine } \\
\text { clearance }\end{array}$ & $70 \pm 22$ & $59 \pm 17$ & $64 \pm 26$ & 0.277 & 0.362 \\
\hline $\begin{array}{l}\text { Loop diretics, } \\
n(\%)\end{array}$ & $17(77)$ & $17(77)$ & $20(95)$ & 0.196 & 0.089 \\
\hline
\end{tabular}

Data are expressed as mean \pm standard deviation (mean \pm S.D.) or median \pm interquartile range (Me \pm IQR). $A L P$, alkaline phosphatase; $\beta$-CTX, $\beta$-CrossLaps; NT-pro-BNP, N-terminal pro-brain natriuretic peptide; $O C$, osteocalcin; OPG, osteoprotegerin; $R A N K L$, receptor activator of nuclear factor $\mathrm{KB}$ ligand; $25(\mathrm{OH}) \mathrm{D}, 25$-hydroxy vitamin $\mathrm{D}$.

(Loncar et al 2010). Recently, it has been shown that serum PTH levels $\geq 47 \mathrm{pg} / \mathrm{ml}$ were optimal cut-off point for hospitalization for heart failure (Sugimato et al. 2009). Secondary hyperparathyroidsm, defined as serum PTH levels higher than $48 \mathrm{pg} / \mathrm{ml}$, was associated with increased mortality and risk of hospitalization in elderly adults (Premaor et al. 2009). Vitamin D insufficiency ( $<50 \mathrm{nmol} / \mathrm{l}$ ) was found in $89 \%$ of $73 \mathrm{CHF}$ patients from our previous cohort. Vitamin D insufficiency usually results in increased PTH secretion in order to maintain calcium homeostasis (Sahota et al. 1999). In our study, we showed that a subgroup of CHF group with vitamin D insufficiency had blunted PTH response namely had functional hypoparathyroidism (FHPT). This subgroup had less advanced heart failure compared to the group who had secondary hyperparathyroidism(SHPT). Therefore, serum PTH response in vitamin D insufficiency may be an important predictor of the severity of CHF. SHPT was also related to increased bone turnover, while there was no difference in renal function between these groups. Importantly in the multivariate analysis, the major determinants of SHPT in CHF patients with vitamin D insufficiency were left ventricular systolic function, adiponectin and marker of 
Table 4. Multivariable logistic regression for PTH status (SHPT versus FHPT) in vitamin D insufficient CHF patients.

\begin{tabular}{lccc}
\hline & OR & $\mathbf{9 5} \% \mathbf{C I}$ & $\mathbf{R}^{\mathbf{2}}$ \\
\hline PTH status & & & \\
Constant $(B=-1.802)$ & 0.165 & & \\
$\quad$ LVEF & 0.832 & $0.705-0.982$ & 0.729 \\
$\quad$ Adiponectin & 1.216 & $0.999-1.480$ & \\
$\quad \beta$-CTx & 1.009 & $1.002-1.015$ & \\
\hline
\end{tabular}

$\beta$-CTX, $\beta$-CrossLaps; $L V E F$, left ventricular ejection fraction.

bone metabolism ( $\beta$-CTx), irrespectively of serum vitamin $\mathrm{D}$ levels and creatinine clearance. These findings seem to be supported by in vitro studies which have shown that adiponectin has induced human osteoblast proliferation and differentiation (Luo et al. 2005). The crosstalk between bone and fat mass was recently enriched by in vivo studies showing that bone markers (osteocalcin) can induce adiponectin expression in adipocytes (Gannagé-Yared et al. 2005, Lee et al. 2007). It is interesting that our finding of adiponectin and marker of bone metabolism as independent determinants of SHPT in CHF patients with vitamin D insufficiency is in accordance with discovered cross regulation between bone and energy metabolism.

Endothelial dysfunction has been previously demonstrated in heart failure syndrome as well as its association with an increased mortality risk (Fischer $e t$ al. 2005, Katz et al. 2005). Furthermore, endothelial dysfunction is detectable by measuring the flow-mediated dilation of the brachial artery (Corretti et al. 2002). We found increased endothelial dysfunction in SHPT patients. Increased serum PTH, as a covariant of CHF, is known to provoke oxidative stress with consequent negative potential influence on vascular function (Chhokar et al. 2005).

The limitations of the study include the relatively small sample size and the cross-sectional design of the study. Nevertheless, because we enrolled a highly selected and clinically stable cohort of elderly male patients with CHF, we could confidently interpret our results. In addition, we did not measure serum ionized calcium or magnesium, which are important determinants of PTH secretion. Vitamin D receptor and calcium sensing receptor-polymorphism are known to have possible impact on PTH levels, but those factors were not studied.

In conclusion, this study provides evidence for an association between increased serum PTH levels and CHF severity. Vitamin D insufficient CHF patients with SHPT showed advanced heart disease compared with those with FHPT. Independent determinants for SHPT in CHF patients with vitamin D insufficiency were left ventricular ejection fraction, adiponectin and $\beta-\mathrm{CTx}$, irrespective of renal function and serum vitamin $D$ levels. Additionally, it could be challenging to investigate whether active vitamin D drug may exhibit suppressive effect on serum PTH without causing serious side-effects such as hypercalcemia in CHF patients. If so, may it have an impact on clinical outcomes?

\section{Conflict of Interest}

There is no conflict of interest.

\section{Acknowledgements}

This work was supported by Serbian Ministry of Science (grant 175033). We thank Merck Sharp \& Dohme for their unrestricted educational grant. This work was also supported by biochemical laboratory "Zavod za laboratorijsku dijagnostiku Konzilijum” Belgrade, Serbia.

\section{References}

ALSAFWAH S, LAGUARDIA S, ARROYO M, DOCKERY B, BHATTACHARYA S, AHOKAS R, NEWMAN K: Congestive heart failure is a systemic illness: a role for minerals and micronutrients. Clin Med Res 5: 238-243, 2007.

ANKER SD, CHUA TP, PONIKOWSKI P, HARRINGTON D, SWAN JW, KOX WJ, POOLE-WILSON PA, COATS

AJ: Hormonal changes and catabolic/anabolic imbalance in chronic heart failure and their importance for cardiac cachexia. Circulation 96: 526-534, 1997.

ANKER SD, CLARK AL, TEIXEIRA MM, HELLEWELL PG, COATS AJ: Loss of bone mineral in patients with cachexia due to chronic heart failure. Am J Cardiol 83: 612-615, 1999.

ATS statement: guidelines for the six-minute walk test. ATS Committee on Proficiency Standards for Clinical Pulmonary Function Laboratories Am J Respir Crit Care Med 166: 111-117, 2002. 
BLEUMINK GS, KNETSCH AM, STURKENBOOM MC, STRAUS SM, HOFMAN A, DECKERS JW, WITTEMAN JC, STRICKER BH: Quantifying the heart failure epidemic: prevalence, incidence rate, life time risk and prognosis of heart failure The Rotterdam Study. Eur Heart J 25: 1614-1619, 2004.

BRAUNWALD E: Biomarkers in heart failure. N Engl J Med 358: 2148-2159, 2008.

CHEN JS, SAMBROOK PN, MARCH L, CAMERON ID, CUMMING RG, SIMPSON JM, SEIBEL MJ: Hypovitaminosis D and parathyroid hormone response in the elderly: effects on bone turnover and mortality. Clin Endocrinol (Oxf) 68: 290-298, 2008.

CHHOKAR VS, SUN Y, BHATTACHARYA SK, AHOKAS RA, MYERS LK, XING Z, SMITH RA, GERLING IC, WEBER KT: Hyperparathyroidism and the calcium paradox of aldosteronism. Circulation 111: 871-878, 2005. COCKROFT DW, GAULT MH: Prediction of creatinine clearance from serum creatinine. Nephron 16: 31-41, 1976.

CORRETTI MC, ANDERSON TJ, BENJAMIN EJ, CELERMAJER D, CHARBONNEAU F, CREAGER MA, DEANFIELD J, DREXLER H, GERHARD-HERMAN M, HERRINGTON D, VALLANCE P, VITA J, VOGEL R: International Brachial Artery Reactivity Task Force. Guidelines for the ultrasound assessment of endothelial-dependent flow-mediated vasodilation of the brachial artery: a report of the International Brachial Artery Reactivity Task Force. J Am Coll Cardiol 39: 257-265, 2002.

DEVEREUX RB, ROMAN MJ, DE SIMONE G, O'GRADY MJ, PARANICAS M, YEH JL, FABSITZ RR, HOWARD BV: Relations of left ventricular mass to demographic and hemodynamic variables in American Indians: the Strong Heart Study. Circulation 96: 1416-1423, 1997.

FISCHER D, ROSSA S, LANDMESSER U, SPIEKERMANN S, ENGBERDING N, HORNIG B, DREXLER H: Endothelial dysfunction in patients with chronic heart failure is independently associated with increased incidence of hospitalization, cardiac transplantation, or death. Eur Heart J 26: 65-69, 2005.

FORMAN JP, GIOVANNUCCI E, HOLMES MD, BISCHOFF-FERRARI HA, TWOROGER SS, WILLETT WC, CURHAN GC: Plasma 25-hydroxyvitamin D levels and risk of incident hypertension. Hypertension 49: 10631069, 2007.

GANNAGÉ-YARED MH, FARES F, SEMAAN M, KHALIFE S, JAMBART S: Circulating osteoprotegerin is correlated with lipid profile, insulin sensitivity, adiponectin and sex steroids in an ageing male population. Clin Endocrinol (Oxf) 64: 652-658, 2006.

GARAKYARAGHI M, KERDEGARI M, SIAVASH M: Calcium and vitamin D status in heart failure patients in Isfahan, Iran. Biol Trace Elem Res 135: 67-73, 2010.

ISAIA G, GIORGINO R, RINI GB, BEVILACQUA M, MAUGERI D, ADAMI S: Prevalence of hypovitaminosis D in elderly women in Italy: clinical consequences and risk factors. Osteoporos Int 14: 577-582, 2003.

KATZ SD, HRYNIEWICZ K, HRILJAC I, BALIDEMAJ K, DIMAYUGA C, HUDAIHED A, YASSKIY A: Vascular endothelial dysfunction and mortality risk in patients with chronic heart failure. Circulation 111: 310-314, 2005.

KENNY AM, BOXER R, WALSH S, HAGER WD: Femoral bone mineral density in patients with heart failure. Osteoporos Int 17: 1420-1427, 2006.

LEE NK, SOWA H, HINOI E, FERRON M, AHN JD, CONFAVREUX C, DACQUIN R, MEE PJ, MCKEE MD, JUNG DY, ZHANG Z, KIM JK, MAUVAIS-JARVIS F, DUCY P, KARSENTY G: Endocrine regulation of energy metabolism by the skeleton. Cell 130: 456-469, 2007.

LEVY D, KENCHAIAH S, LARSON MG, BENJAMIN EJ, KUPKA MJ, HO KK, MURABITO JM, VASAN RS: Long-term trends in the incidence of and survival with heart failure. $N$ Engl J Med 347: 1397-1402, 2002.

LIPS P: Vitamin D deficiency and secondary hyperparathyroidism in the elderly: consequences for bone loss and fractures and therapeutic implications. Endocr Rev 22: 477-501, 2001.

LONCAR G, BOZIC B, DIMKOVIC S, PRODANOVIC N, RADOJICIC Z, CVOROVIC V, PUTNIKOVIC B, POPOVIC V: Association of increased parathyroid hormone with neuroendocrine activation and endothelial dysfunction in elderly men with heart failure. J Endocrinol Invest 34: e78-e85, 2011.

LUO XH, GUO LJ, YUAN LQ, XIE H, ZHOU HD, WU XP, LIAO EY: Adiponectin stimulates human osteoblasts proliferation and differentiation via the MAPK signaling pathway. Exp Cell Res 309: 99-109, 2005.

MOSEKILDE L: Vitamin D and the elderly. Clin Endocrinol (Oxf) 62: 265-281, 2005. 
PIOVESAN A, MOLINERI N, CASASSO F, EMMOLO I, UGLIENGO G, CESARIO F, BORRETTA G: Left ventricular hypertrophy in primary hyperparathyroidism. Effects of successful parathyroidectomy. Clin Endocrinol (Oxf) 50: 321-328, 1999.

PITTAS AG, LAU J, HU FB, DAWSON-HUGHES B: The role of vitamin D and calcium in type 2 diabetes. A systematic review and meta-analysis. J Clin Endocrinol Metab 92: 2017-2029, 2007.

PREMAOR MO, SCALCO R, DA SILVA MJ, FURLANETTO TW: Secondary hyperparathyroidism is associated with increased risk of hospitalization or death in elderly adults living in a geriatric institution. Gerontology 55: 405410, 2009.

RECTOR TS, COHN JN: Assessment of patient outcome with the Minnesota Living with Heart Failure questionnaire: reliability and validity during a randomized, double-blind, placebo-controlled trial of pimobendan. Pimobendan Multicenter Research Group. Am Heart J 124: 1017-1025, 1992.

SAHOTA O, GAYNOR K, HARWOOD RH, HOSKING DJ: Hypovitaminosis D and "functional hypoparathyroidism" - the NoNoF (Nottingham Neck of Femur) study. Age Ageing 30: 467-472, 2001.

SAHOTA O, MASUD T, SAN P, HOSKING DJ: Vitamin D insufficiency increases bone turnover markers and enhances bone loss at the hips in patients with established osteoporosis. Clin Endocrinol (Oxf) 51: 217-221, 1999.

SAHOTA O, MUNDEY MK, SAN P, GODBER IM, HOSKING DJ: Vitamin D insufficiency and the blunted PTH response in established osteoporosis: the role of magnesium deficiency. Osteoporos Int 17: 1013-1021, 2006.

SALEH FN, SCHIRMER H, SUNDSFJORD J, JORDE R: Parathyroid hormone and left ventricular hypertrophy. Eur Heart J 24: 2054-2060, 2003.

SHANE E, MANCINI D, AARONSON K, SILVERBERG SJ, SEIBEL MJ, ADDESSO V, MCMAHON DJ: Bone mass, vitamin D deficiency, and hyperparathyroidism in congestive heart failure. Am J Med 103: 197-207, 1997.

SILVESTRY FE, KERBER RE, BROOK MM, CARROLL JD, EBERMAN KM, GOLDSTEIN SA, HERRMANN HC, HOMMA S, MEHRAN R, PACKER DL, PARISI AF, PULERWITZ T, SEWARD JB, TSANG TS, WOOD MA: Echocardiography-guided interventions. J Am Soc Echocardiogr 22: 213-231, 2009.

SOUBERBIELLE JC, CORMIER C, KINDERMANS C, GAO P, CANTOR T, FORETTE F, BAULIEU EE: Vitamin D status and redefining serum parathyroid hormone reference range in the elderly. J Clin Endocrinol Metab 86: 3086-3090, 2001.

SUGIMOTO T, TANIGAWA T, ONISHI K, FUJIMOTO N, MATSUDA A, NAKAMORI S, MATSUOKA K, NAKAMURA T, KOJI T, ITO M: Serum intact parathyroid hormone levels predict hospitalization for heart failure. Heart 95: 395-398, 2009.

The Criteria Committee of the New York Heart Association Criteria for diagnosis and treatment of heart failure. Little, Brown and Company, 1994.

VIETH R, LADAK Y, WALFISH PG: Age-related changes in the 25-hydroxyvitamin D versus parathyroid hormone relationship suggest a different reason why older adults require more vitamin D. J Clin Endocrinol Metab 88: 185-191, 2003. 